AperTO - Archivio Istituzionale Open Access dell'Università di Torino

Potential of Tourism Sector in Italy as a Means of Entrepreneurship and Growth for Italian companies

This is a pre print version of the following article:

Original Citation:

Availability:

This version is available http://hdl.handle.net/2318/1579377

since 2016-11-26T23:56:39Z

Publisher:

IGI Global Publisher

Terms of use:

Open Access

Anyone can freely access the full text of works made available as "Open Access". Works made available under a Creative Commons license can be used according to the terms and conditions of said license. Use of all other works requires consent of the right holder (author or publisher) if not exempted from copyright protection by the applicable law. 


\title{
Potential of Tourism Sector in Italy as a Means of Entrepreneurship and Growth for Italian companies
}

\author{
Elisa Giacosa \\ University of Turin, Italy \\ Guido Giovando \\ University of Turin, Italy
}

\begin{abstract}
The objectives of this chapter are twofold. First, to verify whether the tourism sector may be considered a means of entrepreneurship and growth for Italian companies. The second goal is to identify the key drivers within the tourism consumption trend, as a consequence of changes in the environment.

Italy is universally renowned for its strong vocation for tourism. The Italian tourism sector is one of the most important to the Italian economy, thanks to the richness of the country's resources. The market seems to be particularly susceptible to external pushes linked to the sociodemographic, cultural, political and economic context, which impact on to the tastes and desires of individuals.

The chapter is structured as follows. The second section analyzes the theoretical background of the topic. The third section outlines the main focus of the chapter. The fourth section presents future research directions for this topic. Finally, the fifth section presents the conclusion of the study.
\end{abstract}

Keywords: tourism sector; Italy tourism sector; eentrepreneurship; growth

\section{INTRODUCTION}

The "tourism sector" belongs to the wider services macro-sector of the "tourism, leisure and communication sector". It is made up of several companies operating in the following activities: hospitality and catering; travel agencies; entertainment; publishing; telecommunications and IT services. Within the tourism sector, this chapter has focused only on the part related to hospitality and catering, travel agencies and entertainment.

The market for Italian tourism companies is split into domestic and foreign: domestic customers are represented by those who live or operate in Italy and by tourists; while the international market refers to those outside of the country.

The research goals of this chapter are twofold. First, to verify whether the tourism sector may be considered a means of entrepreneurship and growth for Italian companies. The second goal is to identify the key drivers within the tourism consumption trend, as a consequence of changes in the socio-demographic, cultural, political and economic behavior of the context under consideration.

The motivation of this research is related to the question of the sustainability of an investment in this sector, due to strong competition from big hotel chains, especially non-Italian ones. In these terms, profound changes in tourism consumption have taken place over the last 20 years in Italy, due to several internal and external socio-demographic, cultural, political and economic factors, which have had a strong impact on companies' activities. In addition, the entrance of big groups into the sector 
(such as big tour operators) has increased the turnover of the sector, thanks to a series of investments which smaller companies have not been able to make. In such a context, the evaluating the business opportunities for tourism companies become interesting, as well as the reasons underlying such market tendencies.

The chapter is structured as follows. The second section of the chapter analyzes the theoretical background of the topic. The third section outlines the main focus of the chapter, with particular reference to issues, controversies and problems. The fourth section presents future research directions for this topic. Finally, the fifth section presents the conclusion of the study.

\section{BACKGROUND}

Companies find their reason to exist in satisfying human needs, and indicating an awareness of a lack (Airoldi, Brunetti, \& Coda, 2005). Human needs can be divided into two different categories (Giacosa, 2011) basic needs and secondary (or higher-level needs). The basic needs are characterized by the need to meet basic requirements such as eating or drinking while the secondary are characterized by the necessity to satisfy desires that are not basic, such as travel and using all the services connected to it. The secondary needs can be generated by wanting to belong to a specific social class, social needs (Montanari, 2003) or by the need, using language consisting of tangible and intangible elements, to achieve a social condition, communication needs (Cappati \& Montanari, 1999).

Tourism is one of the major economic sectors which many countries depend on. For these reasons a series of studies have analysed this sector in general (Aiello, 1996; Buhalis, 1998; Santarelli, 1997; Sciarelli and Rossi, 2007; Tribe, 2011) and its development (Murphy, 2013). Some research has analyzed the companies that move into this sector (Cantino, 1994; Cercola, 1984; Dammacco 1992) and their transformation (Moroni 2008; Montanari, 2004). Particular attention has been paid to aspects related to the marketing of this sector (Holloway, 1994; Pencarelli, 2001; Ryglová, 2011; Sciarelli \& Della Corte, 2003). The concept of brand image has been widely studied by researchers in the area of marketing (Kim \& Kim, 2005; Sahin \& Baloglu, 2011). A careful analysis has been made, in this sector, of a growing demand for higher quality service and on the change in and the evolution of customers (Chen \& Chen 2010; Lee \& Burns, 2004; Vajčnerová \& Ryglová, 2013).

Some scholars have studied the impact on the economic growth of a small tourism-driven economy by an increase in the growth rate of international tourism demand (Shubert, Brida, \& Risso, 2011).

Several researchers have studied particular aspects that drive the tourism sector, such as:

- the effect of wine tourism on the economic growth of the region, on the wine industry and on increasing the profitability and sustainability of tourism in the area (Bailet, Diotallevi, \& Marchini, 2010; Carlsen \& Charters, 2006; Hall, 2003; Hall \& Sharples, 2008; Notta, 2011; Viassone, 2012) and as a representation of a business opportunity for wine companies (Marks, 2011; Ritchie, 2009). This phenomenon of wine tourism has been studied and analyzed showing that every year there is a steady increase (Clemente-Ricolfea, Escribá-Péreza, Rodriguez-Barrioa, \& Buitrago-Veraa, 2012; Groves and Belk, 1998). By attracting tourism, the wine sector has a positive impact on regional competitiveness and its drivers (Jaffe \& Nebenzahl, 2008; Viassone, 2009; Vrontis \& Viassone, 2013; Zanni, 2004).

- health tourism and medical tourism where the health tourism is based on "travel where the primary purpose is treatment in pursuit of better health" and medical tourism "incorporates health screening, hospitalization, and surgical operations" (Henderson, 2004; Saviano, Parida, Caputo, \& Datta Saroj, 2013);

- ecotourism, the experience of domestic tourists and an investigation of the role of authenticity in this experience (Smaoui \& Ben Ali, 2013, Franch, Martinim, Buffa, \& Parisi, 2008);

- sport-tourism where we analyze the increase of tourists interested in sports grounds (Hinch \& Hingham, 2011).

The resources for promoting the tourism sector are limited, so it's important to create and implement a model to appraise the investments made "ex ante", and monitor the investments for returns obtained (Sousa \& Sarmento, 2013).

In addition, the impact of new technologies on the business of tourism, which have given rise to e- 
tourism, has been analysed by several researchers (Addis, 1999; Bing \& Fesenmaier, 2000; Buhalis, 1998; Marcussen, 2001; Missikoff, 2001), as a consequence of the entry of companies providing lowcost, Internet-based tourism services into the market. The Internet channel (Gamble, 1990; Giacosa, 2003) is also profitable in terms of direct sales on behalf of companies, and circumvents the need for middlemen such as tour operators and travel agents (Massaroni, Golinelli, \& Ricotta, 2000).

The present study contributes to expanding the literature via the following two observation points:

- firstly, although some studies have made a comparison between business opportunities in wine sectors and the manufacturing sector (which represents a driving force of the Italian economy) (Giacosa, Giovando, \& Mazzoleni, 2014), no study to date has compared the business opportunities in tourism and the manufacturing sectors; in these terms, this study fills a gap in the literature;

- secondly, the evolution of tourism consumption is observed by using the "input-output" model: distinguishing the general context in which the company operates into various sub-systems, we examined the impact of these sub-systems on the tourism consumption in terms of inputs. In addition, the outputs produced by companies are also considered, because they have an impact on tourism consumption. Previous studies have focused on single factors that influence tourism consumption (e.g. cultural and social factors), or identified a series of factors that influence consumption, but without considering them with respect to the various sub-systems that form the general environment surrounding these companies.

\section{MAIN FOCUS OF THE CHAPTER Issues, Controversies, Problems}

The research goals of this chapter are twofold. Firstly, to verify whether the tourism sector may be considered as a means of entrepreneurship and growth for Italian companies. The second goal is to identify the key drivers within the tourism consumption trend, as a consequence of changes in the socio-demographic, cultural, political and economic behavior of the context in consideration, and also due to the world consumption crisis.

In order to achieve the research objectives, we developed the following hypotheses:

H1: the tourism sector may be considered as a means of entrepreneurship and growth for Italian companies, thanks to the nature of its territory, its favorable climate, its natural and cultural resources in terms of landscapes, culture, food and wines, monuments and history, and the experience of its producers.

With the aim of exploring the hypotheses mentioned above, the research methodology has been carried out in the following phases:

1) First phase: the hypotheses were analyzed by examining the existing literature, both national and international, written about the tourism sector and the drivers in the consumption trend, this highlighted a series of external and internal variables that influence tourism consumption;

2) Second phase: the research methodology was differentiated in relation to the following research goals:

a) The first research goal: the objective is quantitative and thus, the enquiry is also quantitative. The first objective concerns examining the role of the tourism sector for the Italian economic landscape in terms of added value, number of companies and levels of employment from 2000 to 2012 , to verify whether the tourism sector may be considered a means of entrepreneurship and growth for Italian companies. The quantitative data comes from a range of market research, carried out by major Italian trade associations operating in the service sector and market research companies, the research differentiates between Italian and foreign customers;

b) The second research goal: the second goal is to identify the key drivers within the tourism consumption trend, as a consequence of changes in the socio-demographic, cultural, political and economic behavior of the context in consideration. This objective is qualitative in nature - i.e. related to identifying and understanding the factors that give rise to changes in the consumption of tourism in the Italian market.

Firstly, a qualitative survey of the context in which companies operate within the tourism sector was carried out by adopting the input-output model (Ferrero, 1987; Melis, 2001). The companies belong to 
a general environment (Airoldi, Brunetti, \& Coda, 2005; Brusa, 1986; Campedelli, 1998; Saita, 2005), which can be understood as the context in which they operate, which could be divided into a series of sub-systems that affect the company's input-output logic and, as a consequence, impact on the consumption choices of individuals. It was found that the company can be considered as a cell of a living organism, surrounded by its environment, which takes on natural, technological, cultural, social, economic and political characteristics (Cricchio, 1980; Giacosa, Giovando, \& Mazzoleni, 2014; Zappa, 1927). In order to ensure a thorough investigation, we set out the following sub-systems: natural-physical and technological; cultural and social; economic; political-legislative ones. For each sub-system, we analyzed the inputs with the greatest influence on companies' activities and tourism consumption, and the outputs of companies into their environment, which may in turn influence consumption habits.

Secondly, in order to conclude the above qualitative analysis using the input-output model, the qualitative findings derived from 20 interviews with operators (such as managers or owners of major companies) in the sector were aggregated, with the aim of identifying the drivers of major influences on tourism consumption over the last decade, according to the experience of the respondents. These interviews were qualitative in nature, semi-structured (Alvesson \& Deetz, 2000; Corbetta, 2003; Potter $\&$ Wetherell, 1987), and prepared, executed and analyzed by all of the authors.

This study is interested in solving the problem of understanding and identifying business opportunities for the companies in the tourism sector. We tried to solve this problem in the following ways: firstly, considering that the GDP trend within a country influences the economic conditions of the population and creates an impact on consumption, we analyzed this impact on tourism consumption. Secondly, to strengthen this issue, we analyze the impacts on business opportunities of several kinds of factors, such as cultural, social, natural and legislative ones.

\section{Solutions and Recommendations}

In this section, the research results are presented in relation to:

- the role of the tourism sector in the Italian economy;

- the consumption drivers of tourism consumption in Italy.

\section{The role of the tourism sector in the Italian economy}

The role of the tourism sector in the Italian economy is identified by a comparison between the tourism and the manufacturing sectors. The manufacturing sector is a driving force of the Italian economic system.

Firstly, we compared the trends of added value of the Italian tourism sector to the Italian manufacturing sector from 2000 to 2012 (Table 1).

Table 1. Comparison between tourism sector and manufacturing sector (index numbers of value added)

\begin{tabular}{|l|c|c|c|}
\hline & $\mathbf{2 0 0 0}$ & $\mathbf{2 0 1 1}$ & $\mathbf{2 0 1 2}$ \\
\hline Tourism sector & 5.2 & 5.4 & 5.4 \\
\hline Manufacturing sector & 27.7 & 24.8 & 24.2 \\
\hline
\end{tabular}

Source: Confcommercio, 2013

The added value within the tourism sector has been characterized by slight growth between 2000 and 2011, while in 2012 remains equal to 2011. On the other hand, the manufacturing sector is characterized by a significant decrease between 2000 and 2011 that continues in 2012. Therefore, the tourism sector has managed to maintain its size and even to increase it mildly, despite the economic crisis of recent years has managed to maintain its size and even to increase it slightly. From this comparison, the importance of tourism for the Italian economy can be clearly seen, as can its ability to increase value over the time considered. This is in stark contrast to the manufacturing sector.

Secondly, we strengthen the analysis of value added by looking at the number of companies involved in the tourism sector, compared to the total Italian economy (Table 2). 
Table 2 - Companies in the tourism sector

\begin{tabular}{lrrrrrr}
\hline & $\mathbf{2 0 1 1}$ & $\mathbf{\%}$ & $\mathbf{2 0 1 2}$ & $\mathbf{\%}$ & $\mathbf{2 0 1 3}$ & $\mathbf{\%}$ \\
\hline Tourism & $\mathbf{6 0 1 , 0 1 2}$ & $\mathbf{9 . 8}$ & $\mathbf{6 1 3 , 0 0 3}$ & $\mathbf{1 0 . 1}$ & $\mathbf{6 1 8 , 6 9 8}$ & $\mathbf{1 0 . 2}$ \\
& & & & & & \\
Hospitality & 46,800 & 0.8 & 47,661 & 0.8 & $\mathbf{4 8 , 2 2 1}$ & 0.8 \\
$\quad$ Catering & 345,537 & 5.7 & 353,846 & 5.8 & 357,886 & 5.9 \\
\hline Travel agencies & 17,151 & 0.3 & 17,404 & 0.3 & 17,457 & 0.3 \\
\hline$\quad$ Entertainment & 66,334 & 1.1 & 67,601 & 1.1 & 68,015 & 1.1 \\
\hline Total economy & $\mathbf{6 , 1 1 0 , 0 7 4}$ & $\mathbf{1 0 0 . 0}$ & $\mathbf{6 , 0 9 3 , 1 5 8}$ & $\mathbf{1 0 0 . 0}$ & $\mathbf{6 , 0 6 7 , 3 0 5}$ & $\mathbf{1 0 0 . 0}$ \\
\hline Source: Confcommercio, 2013 & & & & & &
\end{tabular}

In Italy, in 2013, the tourism sector includes 618,698 companies (10.2\% of the Italian companies). In particular, $65 \%$ of the companies operate in the field of accommodation and catering, $2.8 \%$ are travel agencies and $11 \%$ work in the entertainment industry (Table 2).

It is shown that the total number of companies in Italy has decreased by $0.7 \%$, while the number of companies belonging to the tourism sector has increased by $10.2 \%$. In particular, there was a steady increase in the number of companies in the tourism sector from $9.8 \%$ in 2011 to $10.2 \%$ in 2013.

Thirdly, the comparison between tourism sector and other sectors is made by looking at employment levels (Table 3).

Table 3 - Average number of full-time employees (*)

\begin{tabular}{|c|c|c|c|}
\hline & 2000 & 2011 & 2012 \\
\hline & $\begin{array}{c}\text { Annual Work } \\
\text { Units }\end{array}$ & $\begin{array}{c}\text { Annual Work } \\
\text { Units }\end{array}$ & $\begin{array}{c}\text { Annual Work } \\
\text { Units }\end{array}$ \\
\hline Agriculture & $6.3 \%$ & $5.1 \%$ & $5.0 \%$ \\
\hline Manufacturing & $28.5 \%$ & $26.1 \%$ & $25.6 \%$ \\
\hline Services & $65.1 \%$ & $68.8 \%$ & $69.4 \%$ \\
\hline - among which: tourism & $6.9 \%$ & $7.7 \%$ & $\mathbf{7 . 8 \%}$ \\
\hline Total & $100.0 \%$ & $100.0 \%$ & $100.0 \%$ \\
\hline
\end{tabular}

Source: Confcommercio, 2013

* Part-time and seasonal employees represent fractions of annual work units.

The tourism sector employs 2.6 million work units, of which 1.5 million units work in the reception and catering area, 290,000 in the entertainment industry, 205,000 in publishing and telecommunications and 398,000 in IT .

It can be seen that the tourism sector follows the opposite trend to other sectors. Indeed, the average number of full-time employees in tourism sector has changed from $6.9 \%$ in 2000 to $7.8 \%$ in 2012, while the agriculture sector changed from $6.3 \%$ in 2000 to $5.0 \%$ in 2012 and the manufacturing sector changed from $28.5 \%$ in 2000 to $25.6 \%$ in 2012.

Since the start of the crisis, world tourism declined until the end of 2009 (UNWTO, 2010) and recovered in 2010. The recovery was confirmed in 2011 (UNWTO, 2011) and is predicted to remain in 2012 and 2013.

Concluding, it appears that the tourism sector in Italy, in these years, has increased both from the point of view of its added value, the number of the companies involved and level of employment.

H1 is confirmed. The tourism sector may be considered a means of entrepreneurship and growth for Italian companies. This is due to the nature of its territory, its favorable climate, its natural and cultural resources in terms of landscapes, culture, food and wines, monuments and history, and the experience of its producers.

\section{The drivers of tourism consumption in Italy}

The consumption trend of individuals may be influenced by the following sub-systems (Giacosa, 2011; Giacosa, Giovando, \& Mazzoleni, 2014):

- Natural-physical and technological; 
- Cultural and social;

- Economic;

- Political and legislative.

\section{1) The natural-physical and technological sub-system}

Natural-physical and technological environment is represented by the natural factors (such as the richness of the territory and the climate) and some factors developed by humans (such as urbanization) which impact on the tourism sector. In particular, according to input-output model, the inputs that influence the tourism consumption are the following:

a) The characteristics of the environment: the variety of the territory in terms of natural features (such as sea, mountains, hills, lakes, etc.), the richness in terms of cultural and historical features and its climate impact on the likelihood of an area to generate tourism. The availability of labor, both in quantitative and qualitative terms, impact on the production and distribution processes and on the opportunities for companies (for example, by the sea during the summer and in the mountains during the winter). Even the availability of transport and communication infrastructures could influence individual consumption, making a place more or less connected with the rest of the world. The characteristics of the environment impact on the types of products offered to tourists and, consequently, on how tourists choose to spend money (Table 4).

Table 4 - The tourist choice in terms of various items of expenditure (millions of euros)

\begin{tabular}{l|r|r|r|r}
\hline $\begin{array}{l}\text { Items of } \\
\text { expenditure }\end{array}$ & \multicolumn{1}{|l|}{ Italians } & Foreigners & \multicolumn{1}{l}{ Total } & Total (\%) \\
\hline $\begin{array}{l}\text { Hospitality } \\
\text { structures }\end{array}$ & 10.724 & 8.944 & 19.668 & 60.9 \\
\hline $\begin{array}{l}\text { Restaurants and } \\
\text { pizzeria }\end{array}$ & 5.234 & 3.448 & 8.682 & 26.9 \\
\hline $\begin{array}{l}\text { Bars, coffee } \\
\text { shops, ice cream } \\
\text { parlours }\end{array}$ & 2.083 & 1.840 & 3.923 & 12.2 \\
\hline $\begin{array}{l}\text { Total for } \\
\text { hospitality and } \\
\text { catering service }\end{array}$ & 18.041 & 14.232 & 32.273 & 100.0 \\
\hline
\end{tabular}

Source: National Tourism Research Institute, 2013 (based on 2010 data)

The expenses for hospitality structures are the highest $(60.9 \%)$, for both Italians and foreigners, followed by restaurants and pizzeria (26.9\%) and then bars, coffee shops and ice cream parlours $(12.2 \%)$. In addition, more then $50 \%$ of hospitality and catering service demand comes from Italian tourists $(56 \%)$. It can be seen that the environment in which companies operate allows them to offer several types of tourism products, which are appreciated by tourists.

b) Demographic factors: tourism consumption is influenced by the characteristics of the population, such as the population growth, the degree of urbanization, the segmentation by age, sex, social class, occupation, the birth and death rates and the number of immigrants. The ageing of the population has changed tourism consumption. In 2020 people aged over 65 will constitute $14.1 \%$ of the population (20\% in 2065), while in 2012 they amounted to $12.3 \%$. This will lead to a change in tourism consumption: after reaching a certain age, the products chosen change, choosing city sightseeing and culture such as art, cruises and not adventure trips, while younger consumers choose different product types.

\section{2) The cultural and social sub-system}

These sub-systems are strongly correlated: 
a) the cultural sub-system influences the values and tastes of consumers, impacting on their choices in terms of consumption and also creating trends in the tourism market. In particular, the level of education, the cultural background and different lifestyles represent important inputs that give rise to changes in tourism consumption in the Italian market. The attention given to improving lifestyle quality increase the consumption of green and healthy tourism, such as beauty spas and bed and breakfasts in the country. The need to save money has increased the consumption of last minute or last second products, while family needs impact on the demands for package-tourism. Cultural factors have generated a change in Italians' choices and preferences regarding tourism consumption in the last decade. There has been a diversification in the consumption of tourism, which is also due to the different ways in which people consume tourism during the year;

b) the social sub-system is represented by the division of society into groups or classes, as well as the relations between these groups and the possibility of social mobility. Since high-end tourism is considered a sort of status symbol, the consumption of expensive tourism products represents a manifestation of a certain level of social status, as well as signaling belonging to a certain class. The consumption of Italian tourism shows much attention to the quality of the product being purchased. This trend is also related to the fact that high-end tourism is a status symbol, so much so that consumers are willing to pay high prices in order to enjoy high-end product.

Cultural and social factors impact on the choice of tourists in terms of tourism products chosen (Table 5).

Table 5 - Tourist consumption in Italy (millions of euros)

\begin{tabular}{l|r|r|r|r}
\hline $\begin{array}{l}\text { Tourism } \\
\text { typology }\end{array}$ & \multicolumn{1}{|c|}{ Italians } & Foreigners & \multicolumn{1}{c|}{ Total } & Total (\%) \\
\hline Holiday houses & 16.906 & 10.199 & 27.105 & $37.4 \%$ \\
\hline $\begin{array}{l}\text { Hospitality } \\
\text { structures }\end{array}$ & 25.486 & 19.821 & 45.307 & $62.6 \%$ \\
\hline Total & 42.392 & 30.020 & 72.412 & $100.0 \%$ \\
\hline
\end{tabular}

Source: National Tourism Research Institute, 2013 (based on 2010 data)

There are more hospitality structures expenses $(62.6 \%)$, compared to the holiday houses ones $(37.4 \%)$.

We then analyzed the demand of Italians for travel (split between Italy and abroad) and their chosen destination (Table 6).

Table 6 - Italians travels and destination (on 100 individuals)

\begin{tabular}{|c|c|c|c|}
\hline Year & Italy & Foreign & Total \\
\hline $\mathbf{2 0 0 9}$ & 23.8 & 6.7 & $\mathbf{2 8 . 0}$ \\
\hline $\mathbf{2 0 1 0}$ & 22.5 & 6.5 & $\mathbf{2 7 . 0}$ \\
\hline $\mathbf{2 0 1 1}$ & 19.6 & 5.4 & $\mathbf{2 3 . 6}$ \\
\hline $\mathbf{2 0 1 2}$ & 18.7 & 6.0 & $\mathbf{2 3 . 2}$ \\
\hline
\end{tabular}

Source Istat, 2013

Between 2009 and 2012, the number of Italian travelers has decreased from 28 to 23.2. Distinguishing between Italian and foreign destinations, the decrease in travelling to Italian destinations was more than the decrease in travelling to foreign destinations. In addition, we looked at each destination of Italian tourists, classifying the types of tourism (Table 7). 
Table 7 - Italians travels classified for country and tourism typologies (EUR/millions)

\begin{tabular}{|c|c|c|c|c|c|c|c|c|c|c|c|c|}
\hline \multirow[t]{2}{*}{$\begin{array}{l}\text { Country } \\
\text { visited }\end{array}$} & \multicolumn{2}{|c|}{ Hotel, Resort } & \multicolumn{2}{|c|}{$\begin{array}{l}\text { House for } \\
\text { rent }\end{array}$} & \multicolumn{2}{|c|}{$\begin{array}{l}\text { Visiting } \\
\text { relatives, } \\
\text { friends }\end{array}$} & \multicolumn{2}{|c|}{ Other } & \multicolumn{2}{|c|}{ No overnight } & \multicolumn{2}{|c|}{ Total } \\
\hline & 2012 & 2013 & 2012 & 2013 & 2012 & 2013 & 2012 & 2013 & 2012 & 2013 & 2012 & 2013 \\
\hline Austria & 324 & 336 & 61 & 93 & 44 & 68 & 79 & 66 & 360 & 333 & 868 & 896 \\
\hline Belgium & 88 & 79 & 27 & 24 & 38 & 38 & 30 & 31 & 1 & 0 & 184 & 172 \\
\hline Croatia & 25 & 35 & 45 & 77 & 18 & 8 & 70 & 39 & 23 & 10 & 181 & 169 \\
\hline France & 975 & 918 & 272 & 227 & 351 & 318 & 336 & 340 & 123 & 130 & 2.057 & 1.933 \\
\hline Germany & 542 & 499 & 149 & 163 & 184 & 200 & 382 & 289 & 41 & 37 & 1.298 & 1.188 \\
\hline Greece & 367 & 353 & 162 & 161 & 54 & 57 & 31 & 42 & 0 & 0 & 614 & 613 \\
\hline Holland & 152 & 174 & 78 & 71 & 44 & 43 & 54 & 53 & 0 & 0 & 328 & 341 \\
\hline Portugal & 125 & 85 & 27 & 19 & 15 & 20 & 14 & 11 & 0 & 0 & 181 & 135 \\
\hline UK & 406 & 380 & 391 & 344 & 239 & 293 & 184 & 170 & 1 & 0 & 1.221 & 1.187 \\
\hline Romania & 54 & 42 & 21 & 18 & 93 & 80 & 26 & 35 & 0 & 0 & 194 & 175 \\
\hline Slovenia & 37 & 33 & 10 & 4 & 5 & 9 & 8 & 12 & 420 & 374 & 480 & 432 \\
\hline Spain & 932 & 820 & 358 & 324 & 193 & 197 & 112 & 82 & 0 & 0 & 1.595 & 1.423 \\
\hline Sweden & 52 & 46 & 11 & 7 & 12 & 18 & 5 & 7 & 0 & 0 & 80 & \begin{tabular}{|l|}
78 \\
\end{tabular} \\
\hline Other & 559 & 574 & 205 & 169 & 187 & 218 & 103 & 92 & 2 & 1 & 1.056 & 1.054 \\
\hline $\begin{array}{l}\text { Total } \\
\text { Europe }\end{array}$ & 4.638 & 4.374 & 1.817 & 1.701 & 1.477 & 1.567 & 1.434 & 1.269 & 971 & 885 & 10.337 & 9.796 \\
\hline Russia & 239 & 265 & 48 & 62 & 65 & 61 & 13 & 14 & 0 & 0 & 365 & 402 \\
\hline Switzerland & 363 & 291 & 82 & 53 & 188 & 148 & 46 & 48 & 662 & 763 & 1.341 & 1.304 \\
\hline Other & 437 & 524 & 76 & 77 & 185 & 237 & 76 & 56 & 2 & 0 & 776 & 894 \\
\hline $\begin{array}{l}\text { Total } \\
\text { Europe } \\
\text { Extra Ue }\end{array}$ & 1.039 & 1.080 & 206 & 192 & 438 & 446 & 135 & 118 & 664 & 763 & 2.482 & 2.600 \\
\hline Brasil & 277 & 213 & 63 & 80 & 82 & 87 & 22 & 27 & 0 & 0 & 444 & 407 \\
\hline Canada & 105 & 85 & 28 & 22 & 58 & 47 & 3 & 6 & 0 & 0 & 194 & 160 \\
\hline Cuba & 49 & 44 & 37 & 21 & 9 & 12 & 1 & 2 & 0 & 0 & 96 & 79 \\
\hline Mexico & 168 & 195 & 10 & 7 & 8 & 9 & 2 & 3 & 0 & 0 & 188 & 214 \\
\hline $\begin{array}{l}\text { United } \\
\text { States of } \\
\text { America }\end{array}$ & 1.428 & 1.275 & 244 & 240 & 237 & 309 & 106 & 95 & 0 & 0 & 2.015 & 1.919 \\
\hline Other & 358 & 293 & 42 & 46 & 116 & 126 & 36 & 24 & 1 & 0 & 553 & 489 \\
\hline $\begin{array}{l}\text { Total } \\
\text { America }\end{array}$ & 2.385 & 2.105 & 424 & 416 & 510 & 590 & 170 & 157 & 1 & 0 & 3.490 & 3.268 \\
\hline Egypt & 322 & 253 & 1 & 6 & 46 & 33 & 33 & 13 & 0 & 0 & 402 & 305 \\
\hline Other & 710 & 764 & 92 & 133 & 221 & 259 & 70 & 80 & 2 & 0 & 1.095 & 1.236 \\
\hline $\begin{array}{l}\text { Total } \\
\text { Africa }\end{array}$ & 1.032 & 1.017 & 93 & 139 & 267 & 292 & 103 & 93 & 2 & 0 & 1.497 & 1.541 \\
\hline China & 519 & 499 & 71 & 108 & 25 & 24 & 14 & 37 & 0 & 0 & 629 & 668 \\
\hline Japan & 109 & 133 & 35 & 16 & 10 & 9 & 10 & 5 & 0 & 0 & 164 & 163 \\
\hline Other & 1.129 & 1.368 & 167 & 216 & 126 & 108 & 46 & 68 & 0 & 0 & 1.468 & 1.760 \\
\hline Total Asia & 1.757 & 2.000 & 273 & 340 & 161 & 141 & 70 & 110 & $\mathbf{0}$ & 0 & 2.261 & 2.591 \\
\hline Australia & 163 & 164 & 110 & 122 & 44 & 68 & 26 & 33 & 0 & 0 & 343 & 387 \\
\hline Other & 54 & 48 & 2 & 6 & 1 & 3 & 8 & 8 & 0 & 0 & 65 & 65 \\
\hline $\begin{array}{l}\text { Total } \\
\text { Oceania }\end{array}$ & 217 & 212 & 112 & 128 & 45 & 71 & 34 & 41 & 0 & 0 & 408 & 452 \\
\hline $\begin{array}{l}\text { Data not } \\
\text { available }\end{array}$ & 17 & 25 & 2 & 2 & 0 & 1 & 18 & 31 & 0 & 0 & 37 & 59 \\
\hline Total & 11.085 & 10.813 & 2.927 & 2.918 & 2.898 & 3.108 & 1.964 & 1.819 & 1.638 & 1.648 & 20.512 & 20.307 \\
\hline
\end{tabular}


We can see how spending is distributed among the different types of Italian traveler accommodation. It can be seen that between 2012 and 2013, there is an increase in spending in the homes of relatives and friends category and generally a decrease in spending in other structures (hotel, resort, rented houses). This shows that the mode of travel is changing with a greater number using the facilities of relatives and friends. This is correlates with the effects of the financial and economic crisis on Italian families. There is also an increase in spending on travel without spending on an overnight stay. This shows a tendency to increase travel to places where they might find free accommodation to minimize travel costs.

In addition, cultural and social factors impact on the choice in terms of product types, location, duration of the holidays, and others. In particular, a series of key factors that influence tourism consumption are (National Tourism Research Institute, 2013):

- The courtesy of the population living in the area (60.8\%);

- The quality and variety of food and beverages (50.6\%);

- The possibilities in terms of leisure, amusement and entertainment (30.8\%);

- How welcoming the hospitality outlets are (29.0\%);

- The country's respect for the environment (22.3\%);

- The cultural offerings (19.9\%);

- The tidiness of the area and of the hospitality structures (16.3\%);

- The competitiveness of food service costs (9.4);

- The competitiveness of accommodation costs $(9.3 \%)$;

- The traffic level (8.9\%);

- The availability of information for tourists $(6.2 \%)$;

- The cost of local transport (2.4\%).

\section{4) The economic sub-system}

The economic sub-system is represented by the general economic system, which dictates the standard of living within a community. In a market economy, the inputs are related to the country's economic situation, and its prospects for development. In addition, companies have an impact on the economic system, as they act as a producer and distributor of wealth, both through the goods and services they produce, and through remuneration for the production factors used.

The economic conditions and consumption habits of the population are strongly interdependent. In fact, populations on a lower income allocate a lower percentage of their income to tourism than to other categories (e.g., eating, medical expenses, clothing, home, education, etc.). On the other hand, greater wealth within a population creates a change in purchasing choices, especially with regard to luxury tourism.

The GDP trend within a country influences the economic conditions of the population and creates an impact on consumption, including tourism consumption. We analyzed the trend of Italian Gross Domestic Product in Italy (GDP) (Table 8).

Table 8 - GDP in Italy - average annual variations (\%)

\begin{tabular}{|l|c|c|c|c|c|c|c|}
\hline & $\mathbf{2 0 0 7}$ & $\mathbf{2 0 0 8}$ & $\mathbf{2 0 0 9}$ & $\mathbf{2 0 1 0}$ & $\mathbf{2 0 1 1}$ & $\mathbf{2 0 1 2}$ & $\mathbf{2 0 1 3}$ \\
\hline GDP ITALY & 1,7 & $-1,2$ & $-5,5$ & 1,7 & 0,5 & $-2,4$ & $-1,9$ \\
\hline
\end{tabular}

Source: Istat, 2013

Italy was affected by a decrease in GDP in 2012, and its prospects for 2013 are negative. The performance of the Italian GDP is one of the factors that may have influenced Italian consumption patterns; this is even clearer when compared with the average for the OECD countries. However, even with the decrease of GDP, the tourism sector trend is increasing.

Table 9 shows the costs (EUR million) for Italian travelers divided by the reason for the trip. 
Table 9 - Expenditure broken down by reason for travel of Italian travelers (EUR/million)

\begin{tabular}{|l|c|c|c|c|c|}
\hline Reason for travel & $\mathbf{2 0 0 9}$ & $\mathbf{2 0 1 0}$ & $\mathbf{2 0 1 1}$ & $\mathbf{2 0 1 2}$ & $\mathbf{2 0 1 3}$ \\
\hline holidays & 8.751 & 9.140 & 9.157 & 8.030 & 7.551 \\
\hline study, courses & 823 & 822 & 958 & 1.275 & 1.156 \\
\hline religious reasons & 99 & 140 & 171 & 130 & 167 \\
\hline care, spa & 194 & 125 & 119 & 95 & 63 \\
\hline honeymooners & 735 & 750 & 865 & 910 & 753 \\
\hline other personal reasons & 3.169 & 3.158 & 2.946 & 3.259 & 3.611 \\
\hline Personal & $\mathbf{1 3 . 7 7 1}$ & $\mathbf{1 4 . 1 3 5}$ & $\mathbf{1 4 . 2 1 6}$ & $\mathbf{1 3 . 6 9 9}$ & $\mathbf{1 3 . 3 0 1}$ \\
\hline seasonal jobs & 277 & 406 & 323 & 489 & 398 \\
\hline conferences, congresses & 350 & 365 & 399 & 309 & 392 \\
\hline other & 5.617 & 5.510 & 5.645 & 6.015 & 6.218 \\
\hline Work/Business & $\mathbf{6 . 2 4 4}$ & $\mathbf{6 . 2 8 1}$ & $\mathbf{6 . 3 6 7}$ & $\mathbf{6 . 8 1 3}$ & $\mathbf{7 . 0 0 8}$ \\
\hline Total & $\mathbf{2 0 . 0 1 5}$ & $\mathbf{2 0 . 4 1 6}$ & $\mathbf{2 0 . 5 8 3}$ & $\mathbf{2 0 . 5 1 2}$ & $\mathbf{2 0 . 3 0 9}$ \\
\hline
\end{tabular}

Source Banca d'Italia, 2014

It emerged that the number of people who travel in recent years has declined, but they spent more (per capita) than in the past. In addition, we can see that in the field "Personal", after an increase in 2010 and 2011, there has been a decrease, while in the "Work / Business" there has been an increase in 2012 and 2013. Basically over the years the total expenditure of Italians in the sector has increased. The total spent for personal reasons is around $65 \%$ of the total expenditure in the field.

In particular, we can see that from 2009 to 2013 has spending on holidays has decreased. In 2009, this expenditure totaled 8,751 while in 2013 it amounted to 7,552 a decrease of $14 \%$. The consequence of the Italian crisis has led families to reduce the cost of traveling for holidays. On the other hand the travel-related courses and studies have increased, going from 823 in 2009 to 1,156 in 2013, an increase of $29 \%$. This shows how, even in the crisis, people are still investing in their training and specialization. Finally, as a logical consequence of the general framework the costs of travel and spa care decreased from 194 in 2009 to 63 in 2013, a dramatic decrease of 68\%.

\section{5) The political-legislative sub-system}

The political-legislative sub-system is represented by the political regime and the legal and legislative environment. This impacts on the legislative framework within which the companies in the tourism sector have to operate. In particular, legislation on companies' activities and tax on tourism consumption may cause a reduction in consumption. Also European community legislation that has impacted on the tourism policies aimed at facilitating young entrepreneurship has influenced the creation and development of companies aimed at enhancing different types of tourism.

Larger companies such as tour operators and hotel chains can influence the political and legislative framework thanks to their bargaining power, and thereby potentially encourage a number of legislative initiatives that will favor companies in the tourism sector (for example, green tourism companies, bed and breakfasts in the country).

H2 is confirmed. The Italian tourism market appears to be particularly susceptible to the pressures of sub-systems which make up the general environment in which the company operates. In particular, the natural-physical and technological; cultural and social; economic; and political-legislative subsystems, which form the above-mentioned general environment, have an impact on the inputs that affect companies in the sector. Also the company may impact its environment in terms of output.

\section{FUTURE RESEARCH DIRECTIONS}

The implications of this study are related to the potential of the tourism sector in Italy. Indeed, this sector represents an interesting area of opportunities for companies. This applies to all the companies involved directly and indirectly in the sector, such as hospitality and catering, travel agencies, tour 
operators, entertainment, publishing companies, communications and promotion companies and IT services.

It has been shown that the tourism sector is an important resource for Italy to be enhanced and implemented in terms of company opportunities. Even with the difficulties of the general economy of the country, the tourism sector is an important one for the Italian economy.

The importance of tourism sector is duly acknowledged in the economic and social framework and, consequently, in the literature and connected business research.

Business studies need to be increased in this field: in recent years, while the manufacturing sector in Italy has declined in terms of value added, number of companies and employment, the tourism sector has had the opposite tendency. In particular, researchers should analyze its ability to attract resources from abroad, with the aim of facing and overcoming the crisis situation in Italy.

In addition, business researches should encourage Italian politician to increase and facilitate investments in the tourism sector, which would be regarded as strategic for the country. Therefore, the development of the tourism sector would compensate for the losses in other sectors.

To overcome the limitations of the research, we suggest comparing the potential and dynamics of the tourism sector with that of other economic sectors, that are representative of the Italian economy, such as fashion, food and wine, home furniture. Additionally, it would be desirable to use suitable econometric models to simulate the impact of a series of exogenous and endogenous variables on the business of tourism.

\section{CONCLUSION}

Italy is universally renowned for its strong attraction for tourists. Consequently, the Italian tourism sector is one of the most important to the Italian economy, thanks to the richness of the country's landscapes and its resources in terms of cultural, human and marketing capabilities. Other factors which positively impact on the appeal to tourists, both Italian and foreign, include the courtesy of the population, the possibilities in terms of entertainment and amusement, the welcome provided by accommodation structures, and the country's respect for the environment.

It emerged that Italy stands out for its tourism production: the ability to produce tourism creates a sort of cult for tourism, affecting the consumption of tourism by Italians.

From the comparison between added value from the Italian tourism sector and manufacturing sectors, the importance of tourism for the Italian economy can be seen, as can its ability to increase value added over the time considered. This is in stark contrast to the manufacturing sector and, as showed, to the trend of the Italian economy. Despite a decrease of Italian GDP in 2012 (and the negative prospects for 2013), the tourism sector trend is increasing. This means that the field shows interesting opportunities for businesses.

This trend can be justified through the input-output model: by observing the dynamics arising from the sub-systems which compose the general environment to which companies belong, we identified some relevant inputs that impact on the companies activities. In addition, the activity of the companies in turn affects consumer attitudes by means of a series of outputs.

The characteristics of the environment impact on the products offered to the tourists and, consequently, on how tourists spend their money in terms of the various items of expenditure.

The drivers of the tourism trend in Italy are linked to several social and cultural factors which influence both the values and tastes of consumers, impacting on their choices in terms of consumption and also creating trends in tourism market, and the division of society into groups or classes, as well as the relations between these groups and the possibility of social mobility.

In economic terms, observing the expenditure pro-capita of Italians, it is shown that the number of people travelling in recent years has declined, but they spent more than in the past. It can be seen that while the number of people travelling in recent years has declined, they spent more (pro-capita) than in the past. In particular, in personal expenditure, after an increase in 2010 and 2011, there has been a decrease, while work expenditure increased in 2012 and 2013. In terms of employment, the tourism sector counters the trend shown in other sectors, because the level of employment has increased. 
The political-legislative sub-system impacts on companies' activities through the legislative framework within which the companies operate. However companies, especially larger companies, could affect the political and legislative framework thanks to their bargaining power.

In conclusion, looking at the tourism sector may create new convenient business opportunities, both from analyzing the trends in individual consumption and by creating the conditions for relevant investments from companies.

\section{REFERENCES}

Airoldi, G., Brunetti, G., \& Coda, V. (2005). Corso di Economia aziendale. Bologna, IT: Il Mulino.

Aiello G. (1996). Economia e tecnica dell'azienda turistica: aziende alberghiere, di viaggio e di ristorazione. Milano, IT: Hoepli.

Banca d'Italia (2014). Indagine sul Turismo Internazionale dell'Italia. Roma, IT: Banca d'Italia Press. Bailet, I., Diotallevi, F., \& Marchini, A. (2010). Determinant factors in reputation of wines: analysis of wine production in Central Italy. Paper, presented at MPRA, University Library of Munich, GE.

Bing, P., \& Fesenmaier, D. R. (2000). A typology of tourism related web sites: its theoretical background and implications. Information Technology and Tourism, 3(4), 155-166.

Brusa L. (1996). La pianificazione strategica. In AA.VV. (Ed.), Lezioni di Economia Aziendale (pp. 122-156). Torino, IT: Giappichelli.

Buhalis D. (1998). Strategic use of information technologies in the tourism industry. Tourism Management, 19(5), 409-421.

Campedelli, B. (1998). Analisi aziendale: strumenti concettuali, metodologici e di valutazione dell'impresa. Torino, IT: Giappichelli.

Cantino, V. (1994). L'economia delle imprese di ristorazione collettiva. Milano, IT: Giuffré.

Cappati, A., \& Montanari, M. (1999). La cucina italiana. Storia di una cultura. Bari-Roma, IT: Laterza.

Carlsen, J. \& Charters, S. (2006). Global Wine Tourism: Research, Management and Marketing. Cambridge, UK: CABI North American Office.

Cercola, R. (1984). Il fast food: strategie e gestione delle aziende di ristorazione rapida. Padova, IT: Cedam.

Chen, C. F., \& Chen, F.S. (2010). Experience quality, perceived value, satisfaction and behavioral intentions for heritage tourists. Tourism Management, 31(1), 29-35.

Clemente-Ricolfea, J. S., Escribá-Péreza, C., Rodriguez-Barrioa J. E., \& Buitrago-Veraa, J. M. (2012). The potential wine tourist market: the case of Valencia (Spain). Journal of Wine Research, 3(2), 8094.

Confcommercio (2013), Rapporto sulle Economie Territoriali e il Terziario di Mercato, Ufficio Studi, novembre 2013, Roma, IT: Confcommercio Press.

Cricchio, S. (1980). L'impresa come momento di origine e di diffusione di fenomeni macro-economici. Milano, IT: Giuffrè.

Dammacco, S. (1992). Le imprese di ristorazione. Milano, IT: Pirola Editore.

Ferrero, G. (1987). Impresa e management. Milano, IT: Giuffré.

Franch, M., Martinim, U., Buffa, F., \& Parisi, G. (2008). 4L tourism (landscape, leisure, learning and limit): responding to new motivations and expectations of tourists to improve the competitiveness of Alpine destinations in a sustainable way. Tourism Review, 63(1), 4-14.

Giacosa, E. (2003). L'economia delle aziende della net economy. Torino, IT, Giappichelli

Giacosa, E. (2011). L'economia delle aziende di abbigliamento. Torino, IT: Giappichelli.

Giacosa, E., Giovando, G., \& Mazzoleni, A. (2014). Wine sector as a driver of growth for the Italian economy. Paper presented in 2nd International Symphosium Systems Thinking for a Sustainable Economy. Advancements in Economic and Managerial Theory and Practice, Refereed Proceedings of Business Systems Laboratory 2nd International Symposium Systems Thinking for a Sustainable Economy. Advancements in Economic and Managerial Theory and Practice, Rome, IT.

Gamble, P. R. (1990). Developing an information technology strategy for hospitality organizations. International Journal of Contemporary Hospitality Management, 19(1), 18-29.

Groves, R., \& Belk, R. (1998). Luxury beverage consumption in Hong Kong. Asia Pacific. Advances Consumer Research, 3(1), 34-37.

Hall, C. M. (2003). Wine, Food, and Tourism Marketing. Binghamton, NY: The Haworth Hospitality Press. 
Hall, C. M., \& Sharples, L. (2008). Food and Wine Festivals and Events Around the World: Development, Management and Markets. Oxford, UK: Butterworth Heinemann.

Henderson, J.C. (2004). Healthcare Tourism in Southeast Asia. Tourism Review International, 7(4), 111-21.

Hinch, T., \& Higham, J. (2011), Sport Tourism Development. Bristol, UK : Datapage International LTD.

Holloway, J. K. (1994). The Business of Tourism, 4rth Edition. London, UK: Pearson Longman.

Istat (Istituto Nazionale di Statistica) (2014). La situazione del Paese, Rapporto Annuale 2014. Roma, IT: Istat Press.

Jaffe, E. D. \& Nebenzahl, I. D. (2006). Made in. Milan, IT: Baldini Castoldi Dalai Editore.

Kim, H-B., \& Kim, W. G. (2005). The relationship between brand equity and firms' performance in luxury hotels and chain restaurants. Tourism Management, 26(1), 549-560.

Lee, J., Graefe, A. R. \& Burns, R. C. (2004). Service quality, satisfaction and behavioral intention among forest visitors. Journal of Travel and Tourism Marketing, 17(1), 73-82.

Marcussen, C. H. (2000). Quantifyng trends in European internet distribution of travel and tourism services. Paper presented at the congress Information Technology \& Strategic tourism Management, University of Westminster, London, UK.

Marks, D. (2011). Competitiveness and the Market for Central and Eastern European Wines: A Cultural Good in the Global Wine Market. Journal of Wine Research, 22(3), 245-263.

Massaroni, E., Golinelli, C., \& Ricotta, E. (2000, October). Intermediari emergenti e figure tradizionali della filiera del turismo. Paper presented at Convegno AIDEA, Genova, IT.

Melis, G. (2001). Elementi di Economia Aziendale. Milano, IT: Giuffrè.

Missikoff, M. (2011). Turismo ed innovazione tecnologica Verso il Web semantico. Paper presente at Conferenza italiana su innovazione e tecnologie dell'informazione per il turismo, Trento, IT.

Montanari, M. (2003). Il cibo come cultura. Bari-Roma, IT: Laterza.

Montanari, A. (2004). Mangiare Fuori. Logiche e Tecniche della ristorazione italiana dall'osteria al fast food. Milano, IT: Edifis.

Moroni, P. (2008). La ristorazione un mestiere che cambia. Milano, IT: Franco Angeli.

Murphy, P. E. (2013). Tourism a community approach. New York, NY: Routledge Library Editions.

National Tourism Research Institute. (2013). Report on Tourism. Retrieved March 10, 2014, from http://www.necstour.eu.

Notta, O., \& Vlachvei, A. (2011). Competitiveness in food and beverage manufacturing industries. In International Conference on Applied Economics, Proceedings of ICOAE (pp. 437-442). Perugia, IT: ICOAE Press.

Pencarelli, T. (2001). Marketing e performance nell'industria turistica. Urbino, IT: Quattroventi.

Ritchie, C. (2009). La cultura di acquisto del vino nel Regno Unito off-trade. International Journal of Wine Business Research, 21(3), 194-211.

Ryglová, K. (2011). The Marketing Tools of Quality Management in Tourism Services. Acta Universitatis Agriculturae et Silviculturae Mendelianae Brunensis, 59(2), 257-266.

Santarelli, E. (1997). La relazione tra dimensione iniziale, sopravvivenza e crescita delle imprese nel settore turistico in Italia. Statistica, 57(1), 125-138.

Saita, M. (2005). I fondamentali dell'economia e strategia aziendale. Milano, IT: Giuffrè.

Saviano, M., Parida, R., Caputo, F., \& Datta, Saroj K. Insights on italian and indian health care systems from vsa perspective. In Book of Proceedings of the 6th Conference Euromed. Confronting Contemporary Business Challenges Through Management Innovation (pp. 1586-1603). Cyprus GR: Euromed Press.

Sciarelli, M., \& Della Corte, V. (2003). Evoluzione del marketing nella filiera turistica: il ruolo dell'information \& Communication Technology. Paper presented at Università degli Studi di Napoli Federico II, Napoli, IT.

Sciarelli, S., \& Rossi, C. (2007). Commercio e turismo: una sinergia da valorizzare, Economia e Diritto del terziario. Cassa di Risparmio di Genova e Imperia Ufficio Studi e Ricerche, 1(2), 315-342. Schubert, S. F., Brida, J. G. \& Risso, W. A. (2011). The impacts of international tourism demand on economic growth of small economies dependent on tourism. Tourism Management, 32(2), 377-385.

Smaoui, F., \& Ben Ali, A. The Ecotourism Experience An Exploratory Study In A Tunisian Context. In Book of Proceedings of the 6th Conference Euromed. Confronting Contemporary Business Challenges Through Management Innovation (pp. 2202-2207). Cyprus GR: Euromed Press. 
Sousa, C. E. J., \& Sarmento, C. M., (2013) Profitable index on tourism promotion on madeira - a financial model, In Book of Proceedings of the 6th Conference Euromed. Confronting Contemporary Business Challenges Through Management Innovation (pp. 2006-2007). Cyprus GR: Euromed Press. Tribe, J. (2011). The Economics of Recreation, Leisure and Tourism. Oxford, UK: Elsevier.

UNWTO (2010), UNWTO World Tourism Barometer. Retrieved March 9, 2014, from http://www.unwto.org.

UNWTO (2011), Barómetro OMT del turismo mundial, Vol. 9. Retrieved March 23, 2014, from http://mkt.unwto.org/sites/all/files/pdf/unwto_barom11_iu_aug_en.pdf.

Istat Istituto Nazionale di Statistica, La situazione del Paese, Rapporto Annuale 2014. Roma, IT: Istat Press.

Vajčnerová, I., \& Ryglová, K. (2013). Significance of quality dimensions in tourism services and their impact on customer decision-making process. In Book of Proceedings of the 6th Conference Euromed. Confronting Contemporary Business Challenges Through Management Innovation (pp. 1844-1856). Cyprus GR: Euromed Press.

Viassone, M. (2009). What makes Piedmont catching up? In D. Vrontis, Y. Weber, R. Kaufmann \& S. Tarba (Ed.), Managerial and Entrepreneurial Developments in the Mediterranean Area, 2nd Annual EuroMed Conference of the EuroMed Academy of Business. Conference Readings Book Proceedings, (pp. 1825-1837). Cyprus GR: EuroMed Press.

Viassone, M. (2012). On the choice of a mountain tourist destination. The evaluation of drivers by young people, Enlightening Tourism. Pathmaking Journal, 2(2), 26-46.

Vrontis, D., \& Viassone, M. (2013). When Wine Meets Territory: The Italian Scenario. In Book of Proceedings of the 6th Conference Euromed. Confronting Contemporary Business Challenges Through Management Innovation (pp. 1898-1909). Cyprus GR: Euromed Press.

Zanni, L. (2004). Leading Firms and wine clusters. Milano, IT, Franco Angeli.

Zappa, G. (1927). Tendenze nuove negli studi di ragioneria. Milano, IT: Istituto Editoriale Scientifico.

\section{ADDITIONAL READING SECTION}

Bing, P., \& Fesenmaier, D. R. (2000). A typology of tourism related web sites: its theoretical background and implications. Information Technology and Tourism, 3(4), 155-166.

Buhalis D. (1998). Strategic use of information technologies in the tourism industry. Tourism Management, 19(5), 409-421.

Carlsen, J. and Charters, S. (2006). Global Wine Tourism: Research, Management and Marketing. Cambridge, UK: CABI North American Office.

Chen, C. F., \& Chen, F. S. (2010). Experience quality, perceived value, satisfaction and behavioral intentions for heritage tourists. Tourism Management, 31(1), 29-35.

Franch, M., Martinim, U., Buffa, F., \& Parisi, G. (2008). 4L tourism (landscape, leisure, learning and limit): responding to new motivations and expectations of tourists to improve the competitiveness of Alpine destinations in a sustainable way. Tourism Review, 63(1), 4-14.

Holloway, J. K. (1994). The Business of Tourism, 4rth Edition. London, UK: Pearson Longman.

UNWTO (2011), Barómetro OMT del turismo mundial, Vol. 9. Retrieved March 23, 2014, from http://mkt.unwto.org/sites/all/files/pdf/unwto_barom11_iu_aug_en.pdf.

Vajčnerová, I., \& Ryglová, K. (2013), Significance of quality dimensions in tourism services and their impact on customer decision-making process. In Book of Proceedings of the 6th Conference Euromed. Confronting Contemporary Business Challenges Through Management Innovation (pp. 1844-1856). Cyprus GR: Euromed Press.

Vrontis, D., \& Viassone, M. (2013). When Wine Meets Territory: The Italian Scenario. In Book of Proceedings of the 6th Conference Euromed. Confronting Contemporary Business Challenges Through Management Innovation (pp. 1898-1909). Cyprus GR: Euromed Press.

\section{KEY TERMS AND DEFINITIONS}

Tourism sector: it belongs to the wider services macro-sector of "tourism, leisure and communication sector" and is made of several types of companies operating in the following activities: hospitality and catering; travel agencies; entertainment; publishing; telecommunications and IT services.

Human needs: these are the needs manifested by each individual, which represent specific life 
necessities dictated by perceptions of aspects that are lacking. Such human needs are perceived according to the framework of a mental rating scale. According to this rating scale, these needs could be classify in different categories: primary needs, which are linked to the necessity to make use of goods that are essential in order to meet basic life conditions; secondary needs, which are represented by aspects that are not necessary in a strict sense.

Company environment: the context in which a company operates, which could be divided into a series of sub-systems, that affect the company's input-output logic and, as a consequence, have an impact on the consumption choices of individuals.

Company sub-systems: these are the parts into which the company environment could be divided. In order to ensure a detailed investigation, the company environment could be divided into the following sub-systems: natural-physical and technological; cultural and social; economic; political-legislative ones.

Natural-physical and technological sub-system: represented by the natural factors and some factors developed by humans which impact on the tourism sector.

Cultural sub-system: influences the values and tastes of consumers, impacting on their choices in terms of consumption and also creating trends in tourism market.

Social sub-system: represented by the division of society into groups or classes, as well as the relations between these groups and the possibility of social mobility.

Economic sub-system: represented by the general economic system, which dictates the living standards within a community.

Political-legislative sub-system: represented by the political regime and the legal and legislative environment, which impact on the legislative framework within which the companies operate. 


\section{A SHORT AUTHOR RESUME}

\section{Elisa Giacosa}

University of Turin, Italy

Department of Management

Corso Unione Sovietica, 218 bis

10134 Torino - Italy

Phone: ++39 0116706013

Email: elisa.giacosa@unito.it

Professor of Financial Accounting

\section{Guido Giovando}

University of Turin, Italy

Department of Management

Corso Unione Sovietica, 218 bis

10134 Torino - Italy

Phone: ++39011 6706015

Email: guido.giovando@unito.it

Professor of Financial Accounting

Elisa Giacosa received a Ph.D. in Business Administration in 2003 and she is currently an Assistant Professor in Business Administration at the Department of Management, University of Turin (Italy), where she teaches Financial Accounting and Net economy (undergraduate). She was Erasmus Visiting Professor in some foreign universities. Her research interests are in family businesses, crisis management, fashion firms, net economy and financial analysis, on which several international publications were focused. She is a Associate Fellow of the EuroMed Academy of Business.

Guido Giovando is Assistant Professor in Business Administration at the University of Turin, Italy. He teaches Financial Accounting and Cost Accounting (Italian undergraduate) and Consolidated Financial Statements (Italian graduate) in the University of Turin, Italy. He was Erasmus Visiting Professor in some Foreign Universities. His research interests are in financial analysis and airport management infrastructures, on which several international publications were focused. He is a Associate Fellow of the EuroMed Academy of Business. 